\title{
Cryotherapy for Actinic Keratosis: Basic Principles and Literature Review
}

\author{
Mariachiara Arisi (D), Edoardo Guasco Pisani, Piergiacomo Calzavara-Pinton, Cristina Zane \\ Department of Dermatology, University of Brescia, ASST Spedali Civili di Brescia, Brescia, Italy \\ Correspondence: Mariachiara Arisi, Department of Dermatology, University of Brescia, ASST Spedali Civili di Brescia, P.le Spedali Civili I, Brescia, \\ 25I23, Italy, Tel +390303995300, Fax +3903039950I5, Email mariachiara.arisi@gmail.com
}

\begin{abstract}
Actinic keratoses (AKs) are pre-malignant epithelial lesions induced by chronic cumulative UV exposure. Several guidelines concerning AKs treatment have been published in the past years. Among destructive procedures, cryotherapy is today considered a standard first-line approach in case of single lesions. The aim of the present review article is to analyse the treatment technique, its efficacy and safety.
\end{abstract}

Keywords: cryotherapy, cryosurgery, actinic keratosis, treatment

\section{Introduction}

Actinic keratosis $(\mathrm{AK})$ is a cutaneous lesion characterized by proliferation of atypical epidermal keratinocytes, induced by chronic cumulative UV exposure with an approximated prevalence ranging between $1 \%$ and $44 \%$ in the adult population. ${ }^{1,2}$ Although it has been shown that AKs can undergo spontaneous regression, the potential to progress into invasive SCC (iSCC) has been extensively demonstrated. ${ }^{3}$

As there are no reliable clinical or histological predictors to distinguish which AK will transform into SCC, ${ }^{4,5}$ treatment of all AKs is always recommended.

Several guidelines concerning AKs treatment have been published in the past years. ${ }^{6-9}$ Among available treatments, lesion- and field-directed therapies should be distinguished. Lesion-directed treatments eliminate atypical keratinocytes in single AKs, while field-directed therapy actions are extended to atypical keratinocytes within a field of chronic sundamaged skin surrounding visible AKs.

Lesion-directed modalities encompass (I) cryosurgery; (II) laser therapy; (III) surgery and (IV) curettage and electrodesiccation. In contrast, field-directed treatments include (I) 5-FU/5FU + salicylic acid; (II) diclofenac 3\% gel; (III) Imiquimod (IMIQ 5\% and 3.75\%); (IV) tirbanibulin 1\% ointment; (V) photodynamic therapy (PDT) ${ }^{10,11}$

Recent works described the use of innovative techniques such as cold atmospheric plasma (CAP) ${ }^{12}$ and microwave therapy. ${ }^{13}$

Among destructive procedures, cryosurgery (also called cryotherapy or cryoablation) is today considered a standard first-line approach in case of single AKs. ${ }^{14}$ It is cheap, rapid and easy to perform. Furthermore, procedure safety and effectiveness do not rely on patient compliance for efficacy.

\section{Cryosurgery Technique}

Cryosurgery is the use of extreme cold produced by a cryogen to destroy normal or abnormal tissues. The first cryogens were liquid air and compressed carbon dioxide snow. In the late 1940s liquid nitrogen (LN) became available and currently it represents the most widely used cryogen by dermatologists. Multiple factors make LN the ideal cryogen in dermatology: low boiling point $\left(-196{ }^{\circ} \mathrm{C}\right)$, transport not requiring pressurization, low production cost, lack of fume toxicity, inflammability and storage in minimally or non-pressurized containers. ${ }^{15}$ 
Cryotherapy freezes and destroys cells based on their variable sensitivity to low temperatures. Pigmented cells are particularly sensitive to damage at -4 to $-7{ }^{\circ} \mathrm{C}$, while keratinocytes are more resistant to cell death at -20 to $-30{ }^{\circ} \mathrm{C}$. The most resistant cells are fibroblasts, which undergo cell death at -30 to $-35{ }^{\circ} \mathrm{C} .{ }^{16}$

The destructive effect of freezing is achieved in two ways: immediate cell destruction (direct effect) and delayed cell destruction (indirect effect). In terms of direct effects, severe freezing will cause the physical effects of cell rupture due to osmotic shock and the formation of intracellular ice, but it will also activate multiple molecular mechanisms of cell death (ie, apoptosis, autophagy, and necrosis). ${ }^{15}$ Indirect effects include vascular and immune ones: as a result of avascular necrosis, due to the formation of vascular thrombosis and microthrombosis, a large number of pathological antigen cells are released, making it vulnerable to host immune surveillance. While physical processes of destruction are effective immediately, physiological-based harmful effects, including cytokine release or apoptosis and secondary necrosis, require several days to complete after treatment.

In cryosurgery, the rapid cooling rate is more destructive. Since the percentage of cell destruction near the application site of low temperature is higher and gradually decreases at the periphery, cell survival may appear in those cells in the distal region of the tissue target or near the active vasculature after treatment. Ideally, a temperature of $-40{ }^{\circ} \mathrm{C}$ should be generated at the edge of the tumour for maximum effect. For this reason, it is strongly recommended to perform a second freezing after the first thawing, as it is additional destructive. ${ }^{15}$

Cryogens can be delivered by using cotton swabs or cryosprays/cryoprobes. The dipstick applicator method is undeniably cheaper; nevertheless, repeated applications may be necessary to achieve effective low temperatures. Therefore, this method is preferable for benign lesions.

In the LN spray technique, a spray probe must be positioned 1-1.5 $\mathrm{cm}$ away from the skin (Figure 1). The jet should be directed to the centre of the lesion until an ice ball develops. There are several main ways to apply spray: in a circular pattern, paintbrush pattern or by a cone according to the diameter of the lesion to be treated. ${ }^{15}$

Before treatment vital areas (eg eyes, nares and ears) should be protected with cotton or cotton gauze. ${ }^{17}$

The freezing time should be adjusted according to the lesion to be treated. ${ }^{18}$ Olsen's I-II AKs are generally treated with a freeze time between 5 and 20s and one freeze-thaw cycle. In case of larger and more hypertrophic lesions longer freeze time should be required. In a study of 92 patients with 5-50 AKs on the face and forearms, the use of two LN spray cycles of 5-10 s and a freeze margin of 1-2 mm induced a significant reduction in count and lesion size. ${ }^{19}$ Longer

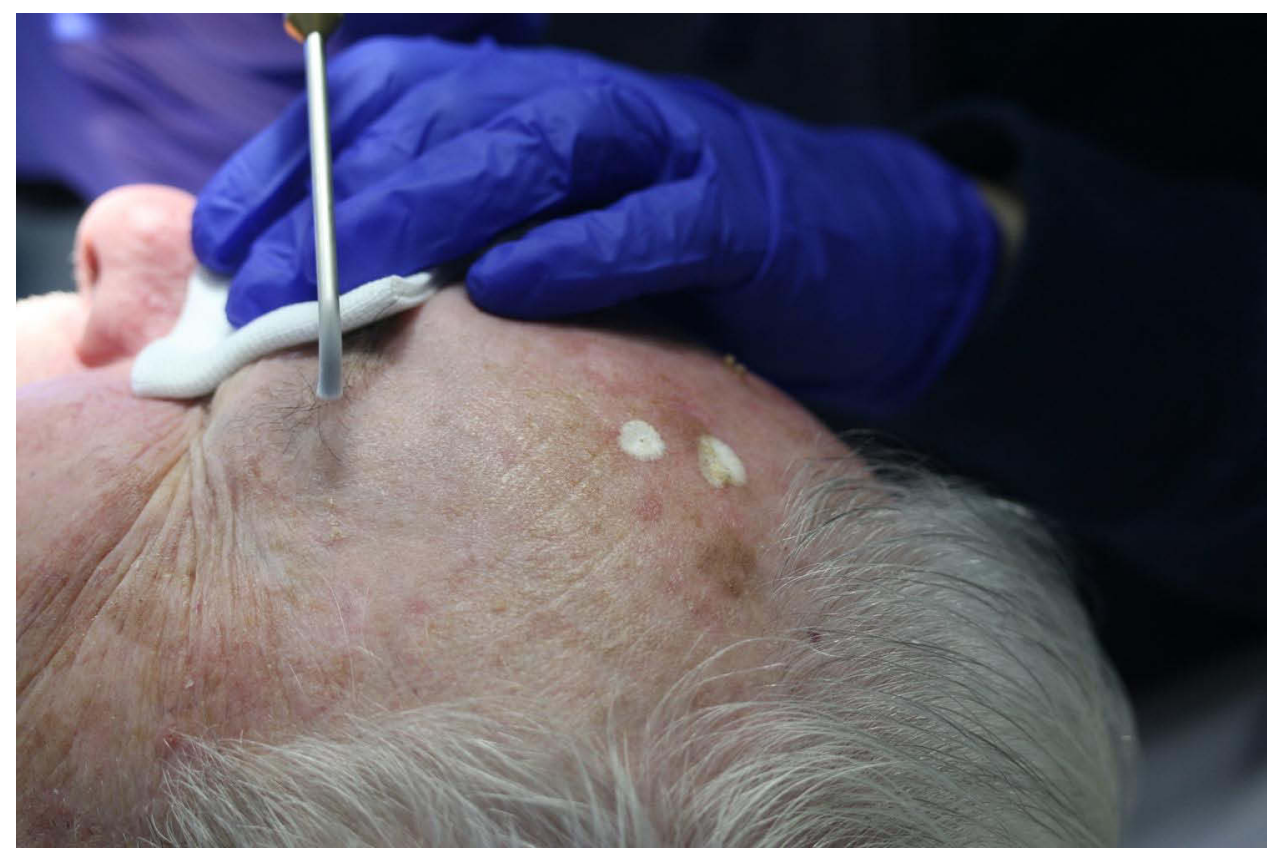

Figure I Cryotherapy LN spray technique for AKs of the face. 
freeze cycles yield better responses: in a prospective study by Thai et $\mathrm{al}^{20}$ clearance rate at 3 months with a single 5 s freeze-thaw cycle was $39 \%$ and $83 \%$ with freezing times over 20 s.

Mota et $\mathrm{al}^{21}$ investigated the efficacy of two different cryotherapy protocols for AKs using reflectance confocal microscopy (RCM): freezing and thawing time of 10 seconds for 1 cycle (group A) or 2 cycles (group B). The latter highlighted superior response in parakeratosis and number of inflammatory cells in epidermis without generating further side effects.

In our experience and according to literature, two freeze-thaw continuous cycles of 10 seconds each are suitable for treating AKs. Treatment of long-time, relapsing or hyperkeratosis lesions need a more aggressive attitude. In the presence of hyperkeratotic scales, it is advisable to perform a gentle curettage of the lesion or to suggest the application of a topical keratolytic agent (based on urea or salicylic acid) at least two weeks before the treatment. ${ }^{17}$ On the contrary, the approach to lesions located at areas of reduced skin thickness (eg eyelids or back of the hands), especially in the atrophic skin of the elderly, requires greater caution in choosing the timing of application. ${ }^{22}$

As in daily practice isolated lesions without any signs of surrounding actinic damage are rarely observed, the use of cryotherapy in many patients may be limited or even discouraged. Thus, the addition of a field-directed treatment can help to overcome the limitations of cryosurgery in patients presenting multiple AKs. ${ }^{23}$ Associating cryotherapy before other field therapies can be useful in case of hyperkeratotic lesions where the penetration of topical drugs alone and consequently their effectiveness can be limited. On the other hand, the likelihood of subclinical lesions progressing to visible AK may be reduced following localized treatment of the lesion site. Conversely, pretreatment of AK with topical drugs may reveal subclinical lesions that can be treated with cryotherapy. Cryosurgery was combined in variable succession with several field treatments such as PDT, 5-FU, or IMIQ to reduce recurrence rates. ${ }^{24-26}$ A systematic review and meta-analysis investigated whether combination intervention was superior to cryosurgery alone: ${ }^{27}$ The former showed significantly higher patient complete clearance rates than cryosurgery alone [risk ratio (RR) $1.74,95 \%$ confidence interval (CI) 1.25-2.43].

Although it must be considered a therapy aimed at the single lesion, cryotherapy can be used alone in the presence of multiple lesions in those patients who did not tolerate or refused other more appropriate field therapies. In this type of patient, several treatment sessions close to each other are recommended and, if immunosuppressed, a close follow-up is strongly recommended to monitor the response to treatment or to evaluate the appearance of suspected tumor lesions.

\section{Complications}

Clinical effects and expected adverse events of cryosurgery should be explained to the patients before the procedure. Patients should be informed about the appearance of erythema and then a wheal a few minutes after starting the procedure, due to histamine release. Oedema develops about 12-36 h post cryosurgery followed by serous or haemorrhagic vesicles. Exudate and crusting may be noted in a few days. Healing time is strongly impacted by the depth of freezing: lesions that have had a deeper freeze will take longer to heal.

Also the body site can influence the healing time after cryotherapy: the face and the back of the hands may require longer recovering times, especially in case of photodamaged and thinned skin of older people.

Pain is an expected outcome of this procedure: ${ }^{28}$ it appears during the procedure and it ends within an hour. It is generally well tolerated by patients so that local anaesthesia is usually not necessary. A recent study of Quinn et $\mathrm{al}^{29}$ measured pain after cryotherapy in 95 AKs patients using a visual analogue scale (VAS) at five time points: prior to treatment, immediately and 10 minutes after treatment, 3 and 24 hours after cryotherapy. Moderate-to-severe pain was reported by $46.3 \%$ of patients immediately after treatment, but only $10 \%$ reported persisting strong pain at following time points. Tolerability of cryotherapy was shown to be independent from clinical characteristics of AKs or patients' personal profile.

As a consequence of melanocyte susceptibility to freezing, local changes in skin pigmentation are the most common and unpleasant complication of cryosurgery. Hypopigmentation is the most common outcome, but also hyperpigmentation can develop in darker skinned individuals. In the scalp or other hairy areas, the destruction of hair follicle cells caused by cold can lead to permanent hair loss. ${ }^{28}$

Scarring is a rare but possible complication of cryotherapy and must therefore be kept in mind by the operator. 
Table I Absolute and Relative Contraindications of Cryotherapy in AKs Patients

\begin{tabular}{|l|l|}
\hline \multicolumn{2}{|l|}{ Contraindications to Cryotherapy } \\
\hline Absolute Contraindications & Relative Contraindications \\
\hline - Lesions that require pathological examination & $\bullet$ Cold intolerance \\
- Lesions located in an area with compromised circulation & $\bullet$ Cold urticaria \\
- Melanoma & $\bullet$ Collagen disease or autoimmune \\
- The patient cannot accept the possibility of pigment changes & disease \\
- Personal history of adverse reaction to cryosurgery & $\bullet$ Concurrent immunosuppressive \\
- Sclerosing or recurrent basal cell carcinoma or squamous cell carcinoma particularly if located in & treatment \\
a high-risk area of the face & $\bullet$ Cryoglobulinemia \\
$\bullet$ Sclerosing basal cell carcinoma or recurrent basal cell or squamous cell carcinoma, particularly when & $\bullet$ Heavily pigmented skin \\
located in a high-risk area (eg Temple, nasolabial fold) & $\bullet$ Lesion located on thin skin areas or \\
& hair-bearing areas \\
& $\bullet$ Multiple myeloma \\
& $\bullet$ Pyoderma gangrenosum \\
\end{tabular}

\section{Contraindications}

In case of AKs, progression to iSCC should be excluded before cryosurgery. When treating pigmented lesions of the face, diagnosis of lentigo maligna (LM) or lentigo maligna melanoma (LMM) should be carefully ruled out. Dermoscopic evaluation is essential to highlight any atypical vessels suggestive of SCC $^{30}$ or atypia of the perifollicular pigmentation suspected for LM/LMM. ${ }^{31}$

Other absolute and relative contraindications of cryotherapy in AKs patients are listed in Table 1.

\section{Efficacy}

When used in AKs treatment, Lubritz et al reported a cure rate of cryotherapy alone of $98.8 \%$ in a study published in $1982,{ }^{32}$ however, a recent study demonstrated a cure rate ranging from $39 \%$ to $83 \%$ depending on freezing protocols. ${ }^{16}$ In a study by Goldberg et $\mathrm{al}^{22}$ where the target surface temperature was standardized at $-5{ }^{\circ} \mathrm{C}$ with an infrared sensor, the cure rate was found to be almost $100 \%$ at 6-week follow-up.

Unfortunately, cryosurgery is still not well standardized and its efficacy strongly depends on the operator and procedure protocol. The freezing time, freezing depth, application time, thawing time and the number of freeze-thaw cycles may vary from different practitioners. ${ }^{22}$ The pressure in the liquid nitrogen tank and the size of the spray gun will affect the number and speed of freezing and might act as confounding factors.

Non-invasive diagnostic techniques such as dermoscopy and $\mathrm{RCM}^{21}$ can be used to assess cryotherapy efficacy. These have also been investigated histologically: $:^{33}$ De Oliveira et $\mathrm{al}^{33}$ reported a reduction in keratinocytes' atypia in $76.9 \%$ of patient treated with cryosurgery together with a thinner epithelium in $69.2 \%$ patients.

\section{Comparison of Cryotherapy with Other Aks Therapies}

Over the years, different studies compared new pharmaceutical or destructive treatments for AKs with LN-cryotherapy (Table 2). ${ }^{32,34-41}$

Krawtchenko et $\mathrm{al}^{37}$ compared cryotherapy, 5-FU and IMIQ 5\% efficacy for AKs treatment in immunocompetent patients. Cure rates were $68 \%$ for cryosurgery vs $96 \%$ for 5 -FU and $85 \%$ for IMIQ. Cryosurgery had the higher recurrence rate at 1 year follow-up ( $28 \%$ vs $54 \%$ for $5 \mathrm{FU}$ and $73 \%$ for IMIQ). ${ }^{37}$

Different studies have analysed the effectiveness of methyl aminolevulinate-photodynamic therapy (MAL-PDT) compared to cryotherapy. ${ }^{34-36,38}$ The prospective randomized study of 193 patients by Szeimies et al ${ }^{34}$ demonstrated higher response rates from 2-freezing-cycles cryotherapy compared to MAL-PDT at 3 months (75\% vs 69\%). Albeit, the cosmetic outcome was judged superior in the PDT group: the 95\% CIs for the difference in excellent and good cosmetic outcome between the treatments were $4.8 \%$ to $26 \%$ (investigator assessment) and $0.7 \%$ to $14.6 \%$ (patient assessment). ${ }^{34}$ 


\begin{tabular}{|c|c|c|c|c|c|c|c|c|}
\hline $\begin{array}{l}\text { First } \\
\text { Author }\end{array}$ & $\begin{array}{l}\text { Study } \\
\text { Design }\end{array}$ & $\begin{array}{l}\text { Enrolled } \\
\text { Patients }\end{array}$ & $\begin{array}{l}\text { Number } \\
\text { of } \\
\text { Lesions }\end{array}$ & Site & Treatment Regimen & $\begin{array}{l}\text { Efficacy }(C R)(3 \\
\text { Months) }\end{array}$ & Cosmetic Outcome & Patient Preference \\
\hline Lubritz et a ${ }^{32}$ & RCT & 200 & 855 & $\begin{array}{l}\text { Face or } \\
\text { scalp }\end{array}$ & $\begin{array}{l}\text { 1) } 2 \text { MAL-PDT sessions, } \\
\text { 2) } 5-15 \text { sec single freeze thaw cryotherapy } \\
\text { 3) placebo PDT }\end{array}$ & $\begin{array}{l}91 \% \text { MAL- PDT, } \\
68 \% \text { cryotherapy, } \\
30 \% \text { placebo PDT } \\
\text { group }\end{array}$ & $\begin{array}{l}\text { Excellent cosmetic outcome: } \\
\text { MAL- PDT } 83 \% \text { compared with } \\
\text { cryotherapy } 51 \%\end{array}$ & Not specified \\
\hline $\begin{array}{l}\text { Szeimies } \\
\text { et a }\left.\right|^{34}\end{array}$ & RCT & 193 & 699 & $\begin{array}{l}\text { Face, scalp } \\
\text { and other } \\
\text { sites }\end{array}$ & $\begin{array}{l}\text { 1) MAL-PDT I session on scalp and face, } 2 \\
\text { sessions in other sites } \\
\text { 2) } 2 \text { cycle cryotherapy (total time } 24 \mathrm{sec} \text { ) }\end{array}$ & $\begin{array}{l}\text { Complete } \\
\text { response in } 69 \% \\
\text { MAL PDT and } \\
75 \% \text { for } \\
\text { Cryotherapy }\end{array}$ & $\begin{array}{l}\text { Excellent or good in } 96.3 \% \\
\text { after MAL PDT and } 80.9 \% \text { after } \\
\text { cryotherapy }\end{array}$ & MAL-PDT \\
\hline $\begin{array}{l}\text { Freeman } \\
\text { et a }\left.\right|^{35}\end{array}$ & RCT & 204 & 855 & $\begin{array}{l}\text { Face or } \\
\text { scalp }\end{array}$ & $\begin{array}{l}\text { 1) Single freeze-thaw cycle }(5-\mid 5 \mathrm{sec}) \\
\text { 2) two cycles of MAL-PDT (day } 0 \text { and day } 7) \\
\text { 3) placebo PDT }\end{array}$ & $\begin{array}{l}91 \% \text { MAL-PDT } \\
68 \% \text { cryotherapy } \\
30 \% \text { placebo PDT }\end{array}$ & $\begin{array}{l}\text { Excellent in } 83 \% \text { of patients } \\
\text { treated with MAL-PDT vs } 51 \% \\
\text { after cryotherapy }\end{array}$ & MAL-PDT \\
\hline $\begin{array}{l}\text { Morton } \\
\text { et al }{ }^{36}\end{array}$ & RCT & 119 & 1501 & $\begin{array}{l}\text { Face and } \\
\text { scalp }\end{array}$ & $\begin{array}{l}\text { I session MAL-PDT, double freeze-thaw } \\
\text { cryotherapy (total time } 16+7 \mathrm{~s} \text { ) }\end{array}$ & $\begin{array}{l}84,4 \% \text { for MAL- } \\
\text { PDT And } 74.5 \% \\
\text { for cryotherapy }\end{array}$ & $\begin{array}{l}\text { Excellent } 70.8 \% \text { in the MAL- } \\
\text { PDT group and } 57.4 \% \text { in the } \\
\text { cryotherapy group }\end{array}$ & MAL-PDT \\
\hline $\begin{array}{l}\text { Krawtchenko } \\
\text { et al }{ }^{37}\end{array}$ & RCT & 75 & 47 & $\begin{array}{l}\text { Head, neck } \\
\text { or décolleté }\end{array}$ & $\begin{array}{l}\text { I-2 courses of cryotherapy, 5FU twice daily } \\
\text { for } 4 \text { weeks } \\
\text { I-2 courses of IMIQ } 5 \% \text { times/week for } 4 \\
\text { weeks each }\end{array}$ & $\begin{array}{l}68 \% \text { after } \\
\text { cryotherapy, } 96 \% \\
\text { after } 5 \mathrm{FU}, 85 \% \\
\text { after IMIQ }\end{array}$ & $\begin{array}{l}\text { (After } 12 \text { months) Excellent in } \\
4 \% \text { after } 5 \mathrm{FU} \text { and cryotherapy } \\
\text { and } 81 \% \text { after IMIQ }\end{array}$ & Not specified \\
\hline $\begin{array}{l}\text { Kaufmann } \\
\text { et al }{ }^{38}\end{array}$ & RCT & 121 & 1343 & $\begin{array}{l}\text { Extremities, } \\
\text { neck and } \\
\text { trunk }\end{array}$ & $\begin{array}{l}\text { Each patient received I MAL- PDT session and } \\
\text { cryotherapy ( } 20 \text { seconds) on alternate sides of } \\
\text { the body (lesions with a non complete } \\
\text { response were retreated after } 12 \text { weeks) }\end{array}$ & $\begin{array}{l}\text { (After } 6 \text { months) } \\
\text { reduction in } \\
\text { lesion count: 88\% } \\
\text { after cryotherapy } \\
\text { and } 78 \text { after } \\
\text { MAL-PDT }\end{array}$ & $\begin{array}{l}\text { (After } 24 \text { weeks) excellent } \\
\text { cosmetic outcome: } 79 \% \text { with } \\
\text { MAL-PDT and } 56 \% \text { with } \\
\text { cryotherapy }\end{array}$ & MAL-PDT \\
\hline $\begin{array}{l}\text { Hauschild } \\
\text { et a }\left.\right|^{39}\end{array}$ & RCT & 349 & 1950 & $\begin{array}{l}\text { Face and } \\
\text { scalp }\end{array}$ & $\begin{array}{l}\text { 1) I session 5-ALA patch-PDT } \\
\text { 2) I session placebo 5-ALA patch-PDT } \\
\text { 3) One cycle of cryotherapy ( } 5 \text { to } 10 \mathrm{sec} \text { of } \\
\text { freezing time) }\end{array}$ & $\begin{array}{l}89 \% \text { with } 5-A L A \\
\text { patch PDT } \\
29 \% \text { with placebo } \\
\text { PDT } 77 \% \text { with } \\
\text { cryotherapy }\end{array}$ & $\begin{array}{l}\text { Excellent in } 68 \% \text { after 5-ALA } \\
\text { patch-PDT, } 42 \% \text { after } \\
\text { cryotherapy and } 60 \% \text { after } \\
\text { placebo-PDT (patient's } \\
\text { assessment) }\end{array}$ & $\begin{array}{l}\text { Very satisfied: } 57 \% \text { after } \\
5 \text {-ALA patch-PDT, 31\% } \\
\text { after cryotherapy and } \\
14 \% \text { after placebo-PDT }\end{array}$ \\
\hline
\end{tabular}


Table 2 (Continued)

\begin{tabular}{|c|c|c|c|c|c|c|c|c|}
\hline $\begin{array}{l}\text { First } \\
\text { Author }\end{array}$ & $\begin{array}{l}\text { Study } \\
\text { Design }\end{array}$ & $\begin{array}{l}\text { Enrolled } \\
\text { Patients }\end{array}$ & $\begin{array}{l}\text { Number } \\
\text { of } \\
\text { Lesions }\end{array}$ & Site & Treatment Regimen & $\begin{array}{c}\text { Efficacy (CR) (3 } \\
\text { Months) }\end{array}$ & Cosmetic Outcome & Patient Preference \\
\hline $\begin{array}{l}\text { Szeimies } \\
\text { et } \mathrm{al}^{40}\end{array}$ & $\mathrm{RCT}$ & 360 & 1619 & $\begin{array}{l}\text { Not } \\
\text { specified }\end{array}$ & $\begin{array}{l}\text { I) I session 5-ALA patch-PDT } \\
\text { 2) I session placebo patch-PDT } \\
\text { 3) one cycle cryo max I0s }\end{array}$ & $\begin{array}{l}83 \% 5-A L A \\
\text { patch-PDT } \\
26 \% \text { placebo-PDT } \\
68 \% \text { cryotherapy }\end{array}$ & $\begin{array}{l}\text { Excellent in } 78 \% \text { after } 5-A L A \\
\text { patch-PDT and placebo-PDT } \\
\text { and } 51 \% \text { after cryotherapy }\end{array}$ & Not specified \\
\hline Zane et $\mathrm{al}^{4 !}$ & RCT & 200 & 543 & $\begin{array}{l}\text { Face and } \\
\text { scalp }\end{array}$ & $\begin{array}{l}\text { One cycle Cryotherapy ( } 10-20 \text { seconds) vs } 2 \\
\text { to } 3 \text { CO2 laser passes ( } 2-3 \mathrm{~W} \text { with } 50 \mathrm{~Hz} \\
\text { repetition). }\end{array}$ & $\begin{array}{l}71.6 \% \text { after } \\
\text { cryotherapy and } \\
65.3 \% \text { CO2 laser }\end{array}$ & $\begin{array}{l}\text { Respectively excellent good } \\
\text { and fair in } 50.7 \%, 35.6 \% \text { and } \\
\text { I3.7\% in cryotherapy vs } 48.4 \% \text {, } \\
43.8 \% \text { and } 7.8 \% \text { after } \mathrm{CO} 2 \\
\text { laser }\end{array}$ & $\begin{array}{l}\text { CRYOTHERAPY } \\
\text { (Excellent in } 59.8 \% \\
\text { after cryotherapy and } \\
24.5 \% \text { after CO2 laser) }\end{array}$ \\
\hline
\end{tabular}

Abbreviations: CR, complete remission; RCT, randomized controlled trial; ALA-PDT, 5-aminolevulinic acid photodynamic therapy; MAL-PDT, methyl aminolevulinate photodynamic therapy; 5FU, 5-fluoruracil; IMIQ, Imiquimod. 
Two sessions of MAL-PDT were found to be more effective than a single-cycle cryotherapy in a study by Freeman et al focused on the treatment of AKs in 204 patients (CR 91 vs 68\%). The overall cosmetic outcome was ranked as excellent in a significantly higher portion of PDT patients compared with the cryotherapy patients (85\% vs $51 \%$ as assessed by investigators and $76 \%$ vs $56 \%$ as assessed by the patient). Hypopigmentation was the most common unappealing local side effect reported after cryosurgery, which occurred in $29 \%$ of patients vs $5 \%$ of PDT ones. ${ }^{35}$

In another split-face randomized controlled study, both treatments were found to have a high cure rate (89\% vs $86 \%)$ 24 weeks after treatment. ${ }^{36}$ One-hundred-nineteen subjects received both a single cycle of MAL-PDT and a double freeze-thaw cryotherapy. Investigators' preference as well as cosmetic outcome favoured MAL-PDT. ${ }^{36}$

More recently, Kaufmann et $\mathrm{al}^{38}$ enrolled 121 patients in a multicentre, randomized, controlled split-face protocol to compare efficacy, cosmetic outcome and patient preference of a single-session of MAL-PDT vs double freeze-thaw cryotherapy. Interestingly, the latter showed a higher efficacy at 24 weeks ( $88 \%$ vs $78 \%$ ) but MAL-PDT confirmed to be the preferred treatment by patients and the one associated with the best aesthetic outcome. ${ }^{38}$

Also, ALA-PDT with self-adhesive patches proved to be more effective than a single cycle of cryotherapy for the treatment of Olsen's I and II AKs of face and scalp. ${ }^{39,40}$

Several reasons can explain the prevalence of MAL-PDT in the cosmetic outcome. First over all, the effect of photorejuvenation induced by MAL-PDT is well known ${ }^{42}$ and could influence the evaluation of the cosmetic result and patients' preference.

In single centre prospective RCT, cryotherapy has been shown to be superior to ablative $\mathrm{CO} 2$ laser for the treatment of isolated AK on the scalp and face. ${ }^{41}$ Two hundred patients bearing 543 AKs were enrolled. Cure rate at 3 months was $78.2 \%$ with cryotherapy and vs $72.4 \%$ with $\mathrm{CO} 2$ laser ablation. The former was more effective for thicker lesions and provided higher remission rates at 12 months follow-up ( $73 \%$ vs $22 \%$ ). No differences in cosmetic outcome rates were reported after 3 months. Overall patients' preference was significantly higher in case of cryosurgery.

\section{Conclusions}

Cryotherapy is an effective and well-tolerated treatment for the treatment of AKs. Since it is not able to treat the field of cancerization, cryotherapy is to be considered a therapy limited to single lesions or at most in association with field therapies in sequential form in case of multiple lesions and wide field of cancerization. The advantages of the method are related to its fast execution, the lack of need for local anaesthesia and its low cost.

The method is not free from contraindications and possible local side effects. In particular, pain during treatment and secondary permanent hypo-/hyperpigmentation may limit patient's acceptance.

However, to date, no standard protocols regarding the time of application of cryogen at different body locations and the duration of freezing-thawing cycles are available. In this context, RCTs are necessary in order to optimize the procedure, reduce its costs and risks of over- or under treatment.

\section{Funding}

There is no funding to report.

\section{Disclosure}

The authors report no conflicts of interest in this work.

\section{References}

1. Naldi L, Chatenoud L, Piccitto R, Colombo P, Placchesi EB, La Vecchia C; Prevalence of Actinic Keratoses Italian Study (PraKtis) Group. Prevalence of actinic keratoses and associated factors in a representative sample of the Italian adult population: results from the prevalence of actinic keratoses Italian study, 2003-2004. Arch Dermatol. 2006;142(6):722-726. doi:10.1001/archderm.142.6.722

2. Frost C, Williams G, Green A. High incidence and regression rates of solar keratoses in a Queensland community. J Invest Dermatol. 2000;115 (2):273-277. doi:10.1046/j.1523-1747.2000.00048.x

3. Werner RN, Sammain A, Erdmann R, Hartmann V, Stockfleth E, Nast A. The natural history of actinic keratosis: a systematic review. Br J Dermatol. 2013;169(3):502-518. doi:10.1111/bjd.12420

4. Fernández-Figueras MT, Carrato C, Sáenz X, et al. Actinic keratosis with atypical basal cells (AK I) is the most common lesion associated with invasive squamous cell carcinoma of the skin. J Eur Acad Dermatol Venereol. 2015;29(5):991-997. doi:10.1111/jdv.12848 
5. Fernandez Figueras MT. From actinic keratosis to squamous cell carcinoma: pathophysiology revisited. J Eur Acad Dermatol Venereol. 2017;31 (Suppl 2):5-7. doi:10.1111/jdv.14151

6. Heppt MV, Leiter U, Steeb T, et al. S3 guideline for actinic keratosis and cutaneous squamous cell carcinoma - short version, part 1: diagnosis, interventions for actinic keratoses, care structures and quality-of-care indicators. J Dtsch Dermatol Ges. 2020;18(3):275-294.

7. Morton CA, Szeimies RM, Basset-Seguin N, et al. European dermatology forum guidelines on topical photodynamic therapy 2019 part 1: treatment delivery and established indications - actinic keratoses, Bowen's disease and basal cell carcinomas. J Eur Acad Dermatol Venereol. 2019;33 (12):2225-2238. doi:10.1111/jdv.16017

8. Peris K, Calzavara-Pinton PG, Neri L, et al. Italian expert consensus for the management of actinic keratosis in immunocompetent patients. $J$ Eur Acad Dermatol Venereol. 2016;30(7):1077-1084. doi:10.1111/jdv.13648

9. de Berker D, McGregor JM, Mohd Mustapa MF, Exton LS, Hughes BR. British association of dermatologists' guidelines for the care of patients with actinic keratosis 2017. Br J Dermatol. 2017;176(1):20-43. doi:10.1111/bjd.15107

10. Dianzani C, Conforti C, Giuffrida R, et al. Current therapies for actinic keratosis. Int J Dermatol. 2020;59(6):677-684. doi:10.1111/ijd.14767

11. Blauvelt A, Kempers S, Lain E, et al. Phase 3 tirbanibulin for actinic keratosis group. phase 3 trials of tirbanibulin ointment for actinic keratosis. $N$ Engl J Med. 2021;384(6):512-520. doi:10.1056/NEJMoa2024040

12. Arisi M, Soglia S, Guasco Pisani E, et al. Cold Atmospheric Plasma (CAP) for the treatment of actinic keratosis and skin field cancerization: clinical and high-frequency ultrasound evaluation. Dermatol Ther. 2021;11(3):855-866. doi:10.1007/s13555-021-00514-y

13. Jackson DN, Hogarth FJ, Sutherland D, Holmes EM, Donnan PT, Proby CM. A feasibility study of microwave therapy for precancerous actinic keratosis. Br J Dermatol. 2020;183(2):222-230. doi:10.1111/bjd.18935

14. Chetty P, Choi F, Mitchell T. Primary care review of actinic keratosis and its therapeutic options: a global perspective. Dermatol Ther. 2015;5 (1):19-35. doi:10.1007/s13555-015-0070-9

15. Abramovits W, Graham G, Har-Shai Y, Strumia R. Dermatological Cryosurgery and Cryotherapy. 1st ed. Springer-Verlag London; 2016.

16. Gage AA. Experimental cryogenic injury of the palate: observations pertinent to cryosurgical destruction of tumors. Cryobiology. 1978;15 (4):415-425. doi:10.1016/0011-2240(78)90060-3

17. Drake LA, Ceilley RI, Cornelison RL, et al. Guidelines of care for cryosurgery. J Am Acad Dermatol. 1994;31:648-653.

18. Nashan D, Meiss F, Müller M. Therapeutic strategies for actinic keratoses-a systematic review. Eur J Dermatol. 2013;23(1):14-32. doi:10.1684/ ejd.2013.1923

19. Ianhez M, Miot HA, Bagatin E. Liquid nitrogen for the treatment of actinic keratosis: a longitudinal assessment. Cryobiology. 2014;69(1):140-143. doi:10.1016/j.cryobiol.2014.06.006

20. Thai KE, Fergin P, Freeman M, et al. A prospective study of the use of cryosurgery for the treatment of actinic keratoses. Int J Dermatol. 2004;43 (9):687-692. doi:10.1111/j.1365-4632.2004.02056.x

21. Mota AN, De Carvalho N, Pellacani G, et al. Reflectance confocal microscopy in actinic keratosis-comparison of efficacy between cryotherapy protocols. Skin Res Technol. 2020;26(6):876-882. doi:10.1111/srt.12889

22. Goldberg LH, Kaplan B, Vergilis-Kalner I, Landau J. Liquid nitrogen: temperature control in the treatment of actinic keratosis. Dermatol Surg. 2010;36(12):1956-1961. doi:10.1111/j.1524-4725.2010.01804.x

23. Steeb T, Wessely A, Leiter U, French LE, Berking C, Heppt MV. The more the better? An appraisal of combination therapies for actinic keratosis. $J$ Eur Acad Dermatol Venereol. 2020;34(4):727-732. doi:10.1111/jdv.15998

24. Lee AD, Jorizzo JL. Optimizing management of actinic keratosis and photodamaged skin: utilizing a stepwise approach. Cutis. 2009;84 (3):169-175.

25. Abadir DM. Combination of topical 5-fluorouracil with cryotherapy for treatment of actinic keratoses. J Dermatol Surg Oncol. 1983;9(5):403-404. doi:10.1111/j.1524-4725.1983.tb00824.x

26. Jorizzo J, Weiss J, Vamvakias G. One-week treatment with $0.5 \%$ fluorouracil cream prior to cryosurgery in patients with actinic keratoses: a double-blind, vehicle-controlled, long-term study. J Drugs Dermatol. 2006;5(2):133-139.

27. Heppt MV, Steeb T, Ruzicka T, Berking C. Cryosurgery combined with topical interventions for actinic keratosis: a systematic review and meta-analysis. Br J Dermatol. 2019;180(4):740-748. doi:10.1111/bjd.17435

28. Prohaska J, Jan AH. Cryotherapy. In: StatPearls [Internet]. Treasure Island (FL): StatPearls Publishing; 2020 [updated August 23, 2020]. Available from: https://www.ncbi.nlm.nih.gov/books/N. Accessed February 22, 2022

29. Quinn G, MacEochagain C, Mac Mahon J, et al. Actinic keratosis: pain severity after cryotherapy and patient tolerability of treatment. $B r$ J Dermatol. 2021;185:234-235. doi:10.1111/bjd.19869

30. Manfredini M, Longo C, Ferrari B, et al. Dermoscopic and reflectance confocal microscopy features of cutaneous squamous cell carcinoma. $J$ Eur Acad Dermatol Venereol. 2017;31(11):1828-1833. doi:10.1111/jdv.14463

31. Lallas A, Argenziano G, Moscarella E, Longo C, Simonetti V, Zalaudek I. Diagnosis and management of facial pigmented macules. Clin Dermatol. 2014;32(1):94-100. doi:10.1016/j.clindermatol.2013.05.030

32. Lubritz RR, Smolewski SA. Cryosurgery cure rate of actinic keratoses. J Am Acad Dermatol. 1982;7(5):631-632. doi:10.1016/S0190-9622(82) 70143-4

33. Oliveira MC, Trevisan F, Pinto CA, Xavier CA, Pinto JC. Histopathological analysis of the therapeutic response to cryotherapy with liquid nitrogen in patients with multiple actinic keratosis. An Bras Dermatol. 2015;90(3):384-389. doi:10.1590/abd1806-4841.20153302

34. Szeimies RM, Karrer S, Radakovic-Fijan S, et al. Photodynamic therapy using topical methyl 5-aminolevulinate compared with cryotherapy for actinic keratosis: a prospective, randomized study. J Am Acad Dermatol. 2002;47(2):258-262. doi:10.1067/mjd.2002.119649

35. Freeman M, Vinciullo C, Francis D, et al. A comparison of photodynamic therapy using topical methyl aminolevulinate (Metvix) with single cycle cryotherapy in patients with actinic keratosis: a prospective, randomized study. J Dermatolog Treat. 2003;14(2):99-106. doi:10.1080/ 09546630310012118

36. Morton C, Campbell S, Gupta G, et al. Intraindividual, right-left comparison of topical methyl aminolaevulinate-photodynamic therapy and cryotherapy in subjects with actinic keratoses: a multicentre, randomized controlled study. Br J Dermatol. 2006;155(5):1029-1036. doi:10.1111/ j.1365-2133.2006.07470.x 
37. Krawtchenko N, Roewert-Huber J, Ulrich M, Mann I, Sterry W, Stockfleth E. A randomised study of topical 5\% imiquimod vs. topical 5-fluorouracil vs. cryosurgery in immunocompetent patients with actinic keratoses: a comparison of clinical and histological outcomes including 1-year follow-up. Br J Dermatol. 2007;157(Suppl 2):34-40. doi:10.1111/j.1365-2133.2007.08271.x

38. Kaufmann R, Spelman L, Weightman W, et al. Multicentre intraindividual randomized trial of topical methyl aminolaevulinate-photodynamic therapy vs. cryotherapy for multiple actinic keratoses on the extremities. Br J Dermatol. 2008;158(5):994-999. doi:10.1111/j.13652133.2008.08488.x

39. Hauschild A, Stockfleth E, Popp G, et al. Optimization of photodynamic therapy with a novel self-adhesive 5-aminolaevulinic acid patch: results of two randomized controlled Phase III studies. Br J Dermatol. 2009;160(5):1066-1074. doi:10.1111/j.1365-2133.2009.09040.x

40. Szeimies RM, Stockfleth E, Popp G, et al. Long-term follow-up of photodynamic therapy with a self-adhesive 5-aminolaevulinic acid patch: 12 months data. Br J Dermatol. 2010;162(2):410-414. doi:10.1111/j.1365-2133.2009.09377.x

41. Zane C, Facchinetti E, Rossi MT, Specchia C, Ortel B, Calzavara-Pinton P. Cryotherapy is preferable to ablative CO2 laser for the treatment of isolated actinic keratoses of the face and scalp: a randomized clinical trial. Br J Dermatol. 2014;170(5):1114-1121. doi:10.1111/bjd.12847

42. Zane C, Capezzera R, Sala R, Venturini M, Calzavara-Pinton P. Clinical and echographic analysis of photodynamic therapy using methylaminolevulinate as sensitizer in the treatment of photodamaged facial skin. Lasers Surg Med. 2007;39(3):203-209. doi:10.1002/1sm.20470

Clinical, Cosmetic and Investigational Dermatology

\section{Publish your work in this journal}

Clinical, Cosmetic and Investigational Dermatology is an international, peer-reviewed, open access, online journal that focuses on the latest clinical and experimental research in all aspects of skin disease and cosmetic interventions. This journal is indexed on CAS. The manuscript management system is completely online and includes a very quick and fair peer-review system, which is all easy to use. Visit http://www. dovepress.com/testimonials.php to read real quotes from published authors.

Submit your manuscript here: https://www.dovepress.com/clinical-cosmetic-and-investigational-dermatology-journal 